\title{
EFFECT OF YOGA EXERCISE ON BLOOD PRESSURE REDUCTION IN THE ELDERLY
}

\author{
Emyk Windartik, Ana Zakiyah \\ School of Health Sciences (STIKes) Bina Sehat PPNI Mojokerto
}

\begin{abstract}
BACKGROUND: High blood pressure (hypertension) can quietly damage body for years before symptoms develop. Left uncontrolled, it may cause disability, poor quality of life or even fatal heart attack. Many studies have shown, with treatment and lifestyle changes, an individual can control high blood pressure to reduce the risk of life-threatening complications. Yoga researchers demonstrate that yoga works because it modulates the physiological system of the body, specifically its effect on the heart rate. Yoga therapy is a multifunctional exercise modality with numerous benefits. Not only does yoga reduce high BP but it has also been demonstrated to effectively reduce blood glucose level, cholesterol level, and body weight. This study aimed to test the generalizability of previous finding about the effectiveness of yoga in reducing in blood pressure, when an elderly population in East Java was used as the target population.

SUBJECT AND METHODS: This was a quasi-experimental study, before and after with control design, conducted in Mojokerto, East Java. A sample of 24 elderly with hypertension who lived in Panti Werdha Majapahit, Brangkal, Mojokerto, East Java, was selected for this study. The dependent variable was blood pressure, measured by mercury sphygmomanometer. The independent variable was yoga exercise. The data was analyzed by paired t-test.

RESULTS: The systolic blood pressure (mmHg) decreased by $25 \mathrm{mmHg}$ from (mean=164; $\mathrm{SD}=13.33$ ) before yoga to (mean=139; $\mathrm{SD}=15.56$ ) after yoga, and it was statistically significant $(\mathrm{p}<0.001)$. The diastolic blood pressure $(\mathrm{mmHg})$ decreased by $13 \mathrm{mmHg}$ from (mean=93; $\mathrm{SD}=3.50$ ) before yoga to (mean=80; $\mathrm{SD}=6.56$ ) after yoga, and it was statistically significant $(\mathrm{p}<0.001)$.
\end{abstract}

CONCLUSION: Yoga exercise effectively reduces both systolic and diastolic blood pressure in the elderly.

Keywords: hypertension, yoga exercise, elderly 